\title{
Development of The Nutrition Pocketbook as a Nutrition Education Media in School
}

\author{
Esi Emilia ${ }^{1}$, Risti Rosmiati ${ }^{1}$, Rachmat Mulyana ${ }^{2}$ \\ Family Welfare Education Department, Engineering Faculty ${ }^{1}$ \\ Civil Department, Engineering Faculty ${ }^{2}$ \\ State University of Medan \\ Medan, Indonesia \\ esiemilia@unimed.ac.id
}

\begin{abstract}
The objectives of the study were to develop the nutrition pocketbook regarding dietary guidelines for adolescents and do the pilot test of the nutrition pocketbook to analyze the nutritional behavior of junior high school students. The research was conducted from March to August 2016 at Three Junior High School (SMP) in Medan city. Fourteen nutritional messages would be designed into the nutrition pocketbook. They were 1) Eat a variety of foods; 2) Consume high fiber foods that eat plenty of vegetables and fruits; 3) Eat breakfast every day; 4) Increase knowledge about nutrition and reproduction health relationship; 5) Consume iron-rich foods; 6) Consume calcium-rich foods; 7) Eat a variety of staple foods; 8) Limit consumption of sweet, salty and fatty foods; 9) Limit consumption of fast foods; 10) Read the labels of packaged foods; 11) Consume safe foods; 12) Do physical activity regularly and maintain a normal weight; 13) No smoking, alcoholic beverages, and drugs; 14) Drink 8 glasses of water a day. The nutrition pocketbook has been designed according to the adolescent needs and validated by nutrition, educational and media experts. Pilot test showed that nutrition pocketbook could increase nutritional behavior of samples.
\end{abstract}

Keywords-adolescent, nutrition education, pocketbook, school

\section{INTRODUCTION}

One of the health development targets is an adolescent as a vulnerable group. The adolescent period is a critical phase in the lifespan of an individual. Adolescence is a time of profound biological and psychosocial change which may affect both diet and weight status. During the period of life from 10 to 21 years, adolescents experience rapid growth, with half of the eventual adult weight and most of peak bone mass accumulated during this time. This dramatic physical growth increases an adolescent's energy, protein, vitamin, and mineral requirements. The nutritional status of adolescents requires close monitoring because they represent the next generation of parents. This heightened physical growth depends upon dieting behavior and socio-economic status. Given the struggle for independence that often occurs as part of adolescent cognitive and social development, adolescent diets are often characterized by healthcompromising eating patterns such as skipping meals, dieting inappropriately, and relying on sugar-sweetened beverages, fast foods, and energy-dense snacks which put them at increased risk for eating disorders, obesity, and chronic diseases such as type II diabetes, metabolic syndrome, and heart disease [1].
Adolescence is a critical period in the life course for both nutrition education and intervention to establish healthy eating patterns and reduce disease risk. Critical nutritional problems of adolescents include obesity, undernutrition, eating disorders and anemia. Unhealthful diets during this critical time may be linked to dramatic changes in body shape, preoccupation with physical appearance, increased autonomy in decision-making, and a growing desire to conform to social pressures [2]. Undernutrition will lower resistance to disease, increased morbidity and stunting, lower level of intelligence and lowered productivity [3]. Obesity, which obesity arises from an imbalance between calories consumed and those expended, has become the most common disease in adolescence [1][4]. Obesity in an adolescent is associated with degenerative diseases and obesity in adulthood [4][5].

Adolescence is a time of increasing autonomy with the reduced parental supervision of meals and snacks. Peer pressure replaces parental authority and poor dietary habits may often be established during the adolescent years. Skipping of meals (especially breakfast) becomes more common and there is increased consumption of snacks, fast foods, sweetened beverages, and foods high in sodium and saturated fats, with reduced intake of fruits, vegetables, dairy products, whole grains, lean meats, and fish [6].

Anemia due to iron deficiency is still a widespread problem in Indonesia. Data from national basic health research in 2013 showed that the proportion of anemia at 514 years old children is $21.7 \%$ [7]. Among adolescent girls, it will bring negative consequences on growth, school performance, morbidity and reproductive performance. Adolescent girls are prospective mothers who will give birth to a baby. To give birth to a normal weight baby, the prospective mother should be healthy and have normal nutritional status.

Approximately 16 million girls aged 15 to 19 years and 2.5 million girls under 16 years give birth each year in developing regions [8]. Data from national basic health research in 2013 showed that the proportion of adolescent pregnancy (15-19 years old) was $1.97 \%$ [7]. In Indonesia, $25 \%$ of adolescents married before 18 years old and followed by the first pregnancy [9]. This prevalence is one of the highest in the East Asia and Pacific region [10].

Many teenagers are unaware that their current eating habits will impact their health status in the future [2]. Since developing healthy dietary and exercise habits in youth leads 
to significant health benefits in adulthood, it is of primary importance to develop programs aimed at establishing such behaviors early in life [11]. Nutrition education is a strategy to prevent disease by growing awareness to consume healthy food, improvement in knowledge about food selection and how to apply this knowledge to healthy eating habits $[12][13][14][15]$. Nutrition educators need to design messages that attract attention, make sense, and help to encourage change in what are often entrenched attitudes and behaviors in the target audience [16]. A study by [17] in high school students found that the higher the nutritional knowledge of adolescents improved attitudes and practices of nutritious food selection. It suggests that increased knowledge in adolescents can change a better attitude and behavior of nutrition.

In 1997 the Ministry of Health issued a General Guideline Balanced Nutrition (PUGS) for an adolescent. These guidelines were developed to assist local health workers in implementing nutrition counseling activities for adolescents. Until now, the program has not been widely known by adolescents. Therefore, the guidelines for nutrition education, especially for teenagers, is essential today. A research by [18] produces ICT-based child nutrition education media which will be used as one of nutrition education media in this research.

This study aimed to develop the nutrition pocketbook regarding dietary guidelines for adolescents and do the pilot test of the nutrition pocketbook to analyze the nutritional behavior of junior high school students.

\section{METHOD}

\section{A. Design, Place and Time}

The study design was descriptive quantitative-qualitative study, conducted in March 2015 until November 2016 in three Junior High Schools in Medan city such as SMPN 7 Medan, SMP Al Ulum Medan, and SMPN 8 Medan.

\section{B. Number and Sampling Technique}

The sample was the student ( $8^{\text {th }}$ grade) of 3 selected schools which was selected by stratified random sampling. The sample size of all three schools were 49 persons.

\section{Types and Modes of Data Collection}

The type of data used in this study is the data on adolescent nutrition behavior. The data consisted of pretest and post-test data, i.e., data before and after socialization of the nutrition pocketbook. The design of the pocketbook is done by writing messages obtained from the low nutritional knowledge of adolescent from previous research and the development of messages through literature studies. The design results are validated by nutrition, educational, and media experts. Expert validation results are revised, then tested the nutrition pocketbook in junior high school students.

\section{Processing and Analysis Data}

The data that have been collected is processed statistically descriptive. The test used is Wilcoxon to analyze the difference in the increase of nutritional behavior before and after given the socialization of the nutrition pocketbook.

\section{RESUlt AND Discussion}

\section{A. The Nutrition Pocketbook Development}

The identification stage was done by determining the nutritional knowledge score of nutritional messages based on the balanced nutrition concept of less than $70 \%$ (low category). The result showed fourteen nutritional messages would be designed into the nutrition pocketbook. Most samples have low knowledge scores about the fourteen nutritional messages. They were 1) Eat a variety of foods; 2) Consume high fiber foods that eat plenty of vegetables and fruits; 3) Eat breakfast every day; 4) Increase knowledge about nutrition and reproduction health relationship; 5) Consume iron-rich foods; 6) Consume calcium-rich foods; 7) Eat a variety of staple foods; 8) Limit consumption of sweet, salty and fatty foods; 9) Limit consumption of fast foods; 10) Read the labels of packaged foods; 11) Consume safe foods; 12) Do physical activity regularly and maintain a normal weight; 13) No smoking, alcoholic beverages, and drugs; 14) Drink 8 glasses of water a day.

Reference [19] has been reviewed on different age groups in the past ten years and concluded that some messages of Indonesia Dietary Guidelines had been better implemented than others; also that information for some messages was not available for which to conclude of its implementation. Also, some practices were identified which are prevalent in several age groups and have significant public health consequence but not yet included in the 13-guidelines. These include smoking, increased intakes of fruit and vegetables, limited intakes of salt and sugar, increased intakes of foods rich in zinc and calcium, handwashing before food preparation and eating, and weight monitoring.

\section{B. Designing of The Nutrition Pocketbook}

The pocketbook is a book with a small size, lightweight, and can be stored in the pocket. So, it would be practical for carrying around and can be read anytime. For example: in a vehicle, waiting for a change of course schedule, or when the teacher was not present. The nutritional pocketbook contained nutritional guidelines for junior high school student was developed based on Indonesia Dietary Guidelines. It is easy to understand and practical for students to apply because the messages are developed in simple, clear, concise and concise language, and practical. Moreover, it provides nutrition education guidelines for a comprehensive school health program. Attractive cover, letters and color design of the nutritional pocketbook could help the student to learn and apply nutritional principles in daily life. A study by [20] showed that storybook is a practical method to elicit changes in eating and activity behaviors.

The pocketbook begins with an explanation of the importance of a healthy life based on the food pyramid. Fourteen messages have been elaborated and designed with concern to 4 things. They are 1) messages should be simple and easy to understand, 2) messages consists of a definition, benefits, and impact as a result of not implementing the messages 3) each message comes with supporting images for better understanding and 4) an explanation of the concept of a healthy lifestyle for adolescents. A review by [16] about the most effective strategy for designing health and nutrition media messages concluded that a nutrition message might use fear appeals. For example, if it included graphic information about health risks associated with a high-fat diet. 
Messages with more intense or graphic content do arouse more audience fear and fear appeals can be persuasive.

\section{Validation}

1) Expert validation: Expert validation is performed to obtain a better nutrition pocketbook according to the proficiency of each expert. They consist of education, nutrition, and media experts. Overall, experts also assess the media appearances based on the suitability of color, image and text display on the material, the standard language used, ease understanding language used, and conformity of the message content with the expected definition.

a) Education expert: Based on discussions with educational experts, the messages delivered in accordance with the subjects matter at the junior high school. However, some messages need improvement especially in the sentence that persuades a person to perform a nutritional behavior. It should be added the benefits of the message. For example in the message "consume iron-rich foods" add the sentence to "consume iron-rich foods to prevent anemia." Overall, the nutrition pocketbook has fulfilled the educational aspect of persuading or forbidding a person in accordance with the messages. Moreover, it has included the benefits or the consequences of not implementing the messages and suggestions. However, some messages need to be simplified so the messages can be understood by adolescents.

b) Nutrition expert: Based on discussions with nutrition experts, the messages delivered in accordance with the principles of nutrition. There are only a few messages that difficult to understand by an adolescent, so it needs an explanation. For example in the message "consume calciumrich foods" word "calcium-rich foods" has not been understood by teenagers. It should be added the explanation of its source (fish etc.) and the benefits of calcium for adolescent growth.

c) Media expert: Overall, the harmony of color, text, and visuals are appropriate. However, there were some messages should be fixed the font size and the color of the letters to make it look clearer when read. For examples on messages "limit consumption of fast food," the letters for the message are given a darker color and for the explanation of message is given a lighter color.

All suggestions from experts in the study and the proposed media are improved. The result of media revision was done by Focus Group Discussion (FGD).

2) Focus Group Discussion (FGD) with students and school staffs: FGDs were conducted on the target groups of students and school staffs consisting of teachers, school medical room, and canteen managers. In general, the designed media has been understood by the target, but on some message, content should be used a more straightforward sentence and more detailed explanation of nutritional terms written. For example "Do physical activity" it should be explained that definition of physical activity is doing activities that move the body including sports. The criteria assessed in the validation of the nutrition pocketbook as follows. a) The simplicity of the media includes easily understood by adolescents, simple but in line with the expected material: The FGD results found that message descriptions are too long and many words are not understood or use scientific words. So, the messages and message descriptions should be simplified.

b) Media according to the characteristics of the adolescents: The FGD results stated that the images used in the nutrition pocketbook are accordance with adolescent favorite such as cartoon pictures.

c) Integration between formats and content: The results of the validation with the target groups suggested the initial image layout on aligning text right should be varied. The format and content of the message are appropriate.

d) The emphasis or essence of the message to be delivered is illustrated on every page: According to the target groups on this item, the messages written are already contained in the description. However, on some messages, the explanation is too long. It needs to be revised and simplified to understand by readers quickly.

e) The balance between animation and text on each page: The FGD results suggested that some animations should be improved and adjusted to the size of the pocketbook and text on each page.

f) The balance of image size and layout of text in each page: The FGD results concluded that there were some images should be fixed in the layout and adjusted to the size of the pocketbook and text on each page.

Based on the FGD results with students and school staffs, it can be concluded that the suggestions from the samples are considered. The nutrition pocketbook will be improved based on expert validation and FGD results. For more details can be seen in Table I.

TABLE I. SUMMARY OF FGD RESULTS WITH STUDENT AND SCHOOL STAFFS

\begin{tabular}{|c|c|c|c|}
\hline No & Messages & FGD Results & Notes \\
\hline 1 & Eat a variety of foods & $\begin{array}{l}\text { Much less the portion } \\
\text { of rice, add pieces of } \\
\text { oranges ( } 1 \text { piece) and } \\
\text { water }\end{array}$ & \\
\hline 2 & $\begin{array}{l}\text { Consume high fiber } \\
\text { foods that eat plenty } \\
\text { of vegetables and } \\
\text { fruits }\end{array}$ & $\begin{array}{l}\text { Image of vegetables } \\
\text { is missing }\end{array}$ & $\begin{array}{ll}\text { Add } & \text { a } \\
\text { vegetable } & \\
\text { image } & \end{array}$ \\
\hline 3 & $\begin{array}{l}\text { Eat breakfast every } \\
\text { day }\end{array}$ & $\begin{array}{l}\text { Add the word } \\
\text { "Let's". Pictures of } \\
\text { lontong r sayur } \\
\text { (vegetable rice cake) } \\
\text { less clear, please look } \\
\text { for a better picture }\end{array}$ & \\
\hline 4 & $\begin{array}{l}\text { Increase knowledge } \\
\text { about nutrition and } \\
\text { reproduction health } \\
\text { relationship }\end{array}$ & $\begin{array}{l}\text { Add pictures of } \\
\text { nursing mothers }\end{array}$ & $\begin{array}{l}\text { Do not } \\
\text { understand } \\
\text { the word } \\
\text { reproductive } \\
\text { health }\end{array}$ \\
\hline 5 & $\begin{array}{l}\text { Consume iron-rich } \\
\text { foods }\end{array}$ & $\begin{array}{l}\text { The word "anemia" } \\
\text { is replaced by "blood } \\
\text { deficiency." }\end{array}$ & $\begin{array}{l}\text { Did not } \\
\text { understand } \\
\text { anemia and } \\
\text { iron }\end{array}$ \\
\hline 6 & $\begin{array}{l}\text { Consume calcium-rich } \\
\text { foods }\end{array}$ & $\begin{array}{l}\text { Replace with the } \\
\text { sentence below: } \\
\text { Eat the side dishes as } \\
\text { a source of calcium }\end{array}$ & $\begin{array}{l}\text { Less } \\
\text { understandin } \\
\mathrm{g} \text { of the word } \\
\text { calcium }\end{array}$ \\
\hline
\end{tabular}




\begin{tabular}{|c|c|c|c|}
\hline No & Messages & FGD Results & Notes \\
\hline 7 & $\begin{array}{l}\text { Eat a variety of staple } \\
\text { foods }\end{array}$ & $\begin{array}{l}\text { Add a picture of } \\
\text { tubers (local food). } \\
\text { The picture is more } \\
\text { representative of the } \\
\text { staple food of wheat } \\
\text { and its preparations. } \\
\text { Add the word } \\
\text { "Let's." }\end{array}$ & \\
\hline 8 & $\begin{array}{l}\text { Limit consumption of } \\
\text { sweet, salty and fatty } \\
\text { foods }\end{array}$ & $\begin{array}{l}\text { There are no } \\
\text { messages for sugar } \\
\text { and fat. The } \\
\text { description } \\
\text { changed to: } \\
\text { "Consuming iodized } \\
\text { salt can improve } \\
\text { brain intelligence and } \\
\text { prevent mumps." } \\
\text { Monotone color, blue } \\
\text { shirt }\end{array}$ & $\begin{array}{l}\text { Did not } \\
\text { understand } \\
\text { the iodine } \\
\text { words }\end{array}$ \\
\hline 9 & $\begin{array}{l}\text { Limit consumption of } \\
\text { fast foods }\end{array}$ & $\begin{array}{l}\text { Replace with the } \\
\text { sentence below: } \\
\text { Fast food contains } \\
\text { high fat, salt, and } \\
\text { carbohydrates. Too } \\
\text { often eat fast food } \\
\text { could cause } \\
\text { hypertension, } \\
\text { diabetes, coronary } \\
\text { heart disease and } \\
\text { cancer }\end{array}$ & $\begin{array}{l}\text { Words too } \\
\text { scientific }\end{array}$ \\
\hline 10 & $\begin{array}{l}\text { Read the labels of } \\
\text { packaged foods }\end{array}$ & Ok & \\
\hline 11 & Consume safe foods & Ok & \\
\hline 12 & $\begin{array}{l}\text { Do physical activity } \\
\text { regularly and maintain } \\
\text { a normal weight }\end{array}$ & $\begin{array}{l}\text { "Do it." } \\
\text { Add pictures of } \\
\text { physical activity such } \\
\text { as sweeping pages } \\
\text { and washing dishes. } \\
\text { Replace the word } \\
\text { "monitor" } \\
\text { "weigh." }\end{array}$ & \\
\hline 13 & $\begin{array}{l}\text { No smoking, alcoholic } \\
\text { beverages, and drugs }\end{array}$ & $\begin{array}{l}\text { Crossed the picture } \\
\text { of cigarettes, not the } \\
\text { smoking person. } \\
\text { Replace the word } \\
\text { "illegal drugs" with } \\
\text { "drugs." }\end{array}$ & \\
\hline 14 & $\begin{array}{l}\text { Drink eight glasses of } \\
\text { water a day }\end{array}$ & Ok & \\
\hline
\end{tabular}

\section{Pilot test of the nutrition pocketbook}

The nutrition pocketbook has been revised based on a suggestion from expert and FGD results. The pilot test was conducted to analyze how much the nutritional behavior increase, especially the student knowledge after the media has been socialized. Tests were conducted on 49 students from two classes and were randomly assigned. The results of the pilot test can be seen in Table II.

Table II showed the distribution of adolescent nutritional behavior consisting of knowledge, attitude and practice of nutrition. Overall, more than half the nutritional knowledge and practice level of the sample was in a low category $(67.3 \%$ and $75.5 \%)$, and the rest are in the medium category. Only $4.76 \%$ of samples had high nutritional behavior. After the socialization, the sample who had high nutritional behavior increase to $87.8 \%$. The average score of the nutritional behavior is present in Table III.
TABLE II. DistRIBUTION OF ADOLESCENT NUTRITIONAL BEHAVIOR

\begin{tabular}{|c|c|c|c|c|c|c|c|c|}
\hline & \multicolumn{2}{|c|}{ Knowledge } & \multicolumn{2}{|c|}{ Attitude } & \multicolumn{2}{|c|}{ Practice } & \multicolumn{2}{|c|}{ Total } \\
\hline & $P r e^{a}$ & Post $t^{b}$ & $\operatorname{Pre}^{a}$ & Post $t^{b}$ & $P r e^{a}$ & Post & $\operatorname{Pre}^{a}$ & Post $t^{b}$ \\
\hline High & 2.04 & 89.8 & $\begin{array}{l}12 . \\
2\end{array}$ & 91.8 & 0 & 81.6 & 4.76 & 87.8 \\
\hline $\begin{array}{l}\text { Mediu } \\
\mathrm{m}\end{array}$ & 30.6 & 10.2 & $\begin{array}{l}40 . \\
8\end{array}$ & 8.16 & 24.5 & 18.4 & 32 & 12.2 \\
\hline Low & 67.3 & 0 & $\begin{array}{l}46 . \\
9 \\
\end{array}$ & 0 & 75.5 & 0 & 63.3 & 0 \\
\hline Total & 100 & 100 & 100 & 100 & 100 & 100 & 100 & 100 \\
\hline
\end{tabular}

TABLE III. The Average SCORE OF THE Nutritional BEHAVIOR OF SAMPLES

\begin{tabular}{|c|l|c|c|c|c|}
\hline No & $\begin{array}{c}\text { Nutritional } \\
\text { Behavior }\end{array}$ & Pretest & Posttest & Delta & $\boldsymbol{P}$ \\
\hline 1 & Knowledge & $49.9 \pm 15.2$ & $83.7 \pm 5.8$ & 33.8 & $\mathrm{P}<0.05$ \\
\hline 2 & Attitude & $58.6 \pm 20.3$ & $86.6 \pm 5.2$ & 28.0 & $\mathrm{P}<0.05$ \\
\hline 3 & Practice & $52.1 \pm 25.1$ & $89.4 \pm 7.8$ & 37.3 & $\mathrm{P}<0.05$ \\
\hline & Total & $53.5 \pm 20.2$ & $86.6 \pm 6.3$ & 33.1 & $\mathrm{P}<0.05$ \\
\hline
\end{tabular}

Table III showed that there was a significant increase in sample nutritional behavior before the trial by $53.5 \%$ to $86.6 \%$ after the trial. Table shows increased knowledge, attitudes, and practice of nutrition in high category $89.8 \%$; $91.8 \%$ and $81.6 \%$ respectively. Overall, the three aspects assessed were knowledge, attitudes and nutritional practices had significant improvement. The average increase for these three aspects was $33.03 \%$ with details of $33.8 \%$ improvement in nutritional knowledge, 28\% nutrition attitudes and $37.3 \%$ improvement in nutrition practice. It can be concluded that the increase of knowledge, attitude, and practice of nutrition because using media produced in this research.

\section{CONCLUSION}

Fourteen nutritional messages would be designed into the nutrition pocketbook. They were 1) Eat a variety of foods; 2) Consume high fiber foods that eat plenty of vegetables and fruits; 3) Eat breakfast every day; 4) Increase knowledge about nutrition and reproduction health relationship; 5) Consume iron-rich foods; 6) Consume calcium-rich foods; 7) Eat a variety of staple foods; 8) Limit consumption of sweet, salty and fatty foods; 9) Limit consumption of fast foods; 10) Read the labels of packaged foods; 11) Consume safe foods; 12) Do physical activity regularly and maintain a normal weight; 13) No smoking, alcoholic beverages, and drugs; 14) Drink 8 glasses of water a day. The nutrition pocketbook has been designed according to the adolescent needs and validated by nutrition, educational and media experts. Pilot test showed that nutrition pocketbook could increase nutritional behavior of samples.

\section{ACKNOWLEDGMENT}

This research was supported by The Ministries of Research, Technology and Higher Education, Indonesia. 


\section{REFERENCES}

[1] E. W. Evans and C. Lo, "Adolescents: Nutritional Problems of Adolescents," Encycl. Hum. Nutr., vol. 1-4, pp. 14-22, 2012.

[2] J. Stang and M. T. Story, Guidelines for adolescent nutrition services. Minneapolis: Center for Leadership, Education and Training in Maternal and Child Nutrition, Division of Epidemiology and Community Health, School of Public Health, University of Minnesota, 2005.

[3] V. J. B. Matrins et al., "Long-lasting effects of undernutrition," Int. J. Environ. Res. Public Health, vol. 8, no. 6, pp. 1817-1846, 2011.

[4] B. M. Popkin, "The nutrition transition in the developing world," Dev. Policy Rev., vol. 21, no. 5-6, pp. 581-597, 2003.

[5] J. L. Mahoney and H. Lord, "Afterschool Program Participation and the Development of Child Obesity and Peer Acceptance," Appl. Dev. Sci., vol. 9, no. 4, pp. 202-215, 2005.

[6] M. R. Corkins et al., "Nutrition in Children and Adolescents," Med. Clin. North Am., vol. 100, no. 6, pp. 1217-1235, 2016.

[7] Badan Penelitian dan Pengembangan Kesehatan, "Riset Kesehatan Dasar (RISKESDAS) 2013,” 2013.

[8] S. Neal, Z. Matthews, M. Frost, H. Fogstad, A. V. Camacho, and L. Laski, "Childbearing in adolescents aged 12-15 years in low resource countries: A neglected issue. New estimates from demographic and household surveys in 42 countries," Acta Obstet. Gynecol. Scand., vol. 91, no. 9, pp. 1114-1118, 2012.

[9] Badan Pusat Statistik, "Kemajuan yang Tertunda: Analisis Data Perkawinan Usia Anak di Indonesia," 2016.

[10] U. N. C. F. Unicef, "Ending Child Marriage: Progress and prospects," 2014

[11] S. R. Daniels, C. A. Pratt, and L. L. Hayman, "Reduction of risk for cardiovascular disease in children and adolescents," Circulation, vol. 124 , no. 15 , pp. $1673-1686,2011$.
[12] J. Lee, S. Jeong, G. Go, H. Park, and Y. Ko, "Development of a Food Safety and Nutrition Education Program for Adolescents by Applying Social Cognitive Theory," Osong Public Heal. Res. Perspect., vol. 7, no. 4, 2016.

[13] M. Sandell et al., "Future for food education of children," Futures, vol. 83, pp. 15-23, 2016.

[14] M. Cunha, L. Saboga-Nunes, and B. Cunha, "Education for Health, Dietary Habits, Nutritional Status and Indicators of Metabolic Risk," Procedia - Soc. Behav. Sci., vol. 237, no. June 2016, pp. 875-881, 2017.

[15] D. K. S. Bártlová, "Eating habits of adolescents and education by nurses on primary prevention - ScienceDirect," vol. 9, pp. e186-e191, 2017.

[16] B. J. Wilson, "Designing media messages about health and nutrition: what strategies are most effective?," J. Nutr. Educ. Behav., vol. 39, pp. S13-S19, 2007.

[17] E. Emilia, "The floating tool measuring knowledge, attitudes and behavior of nutrition in adolescents," Bogor Agricultural University, 2008.

[18] E. Emilia, "Nutrition Education Media Development ICT-based Child Friendly," in Widyakarya National Food and Nutrition X, 2012.

[19] A. A. Usfar and U. Fahmida, "Do Indonesians follow its Dietary Guidelines? - evidence related to food consumption, healthy lifestyle, and nutritional status within the period 2000-2010," Asia Pac. J. Clin. Nutr., vol. 20, no. 3, pp. 484-494, 2011.

[20] L. Bellows, A. Spaeth, V. Lee, and J. Anderson, "Exploring the use of storybooks to reach mothers of preschoolers with nutrition and physical activity messages," J. Nutr. Educ. Behav., vol. 45, no. 4, pp. 362-367, 2013.

$[21]$ 